\title{
Activation of temperature-dependent flagellar movement of demembranated fowl spermatozoa: involvement of an endogenous serine protease
}

\author{
K. Ashizawa ${ }^{1}$, S. Katayama $^{1}$, G. J. Wishart ${ }^{2}$, A. Shiraishi ${ }^{1}$ and \\ Y. Tsuzuki ${ }^{1}$ \\ ${ }^{1}$ Laboratory of Animal Reproduction, Faculty of Agriculture, Miyazaki University, Miyazaki 889-21, \\ Japan; and ${ }^{2}$ Department of Molecular and Life Sciences, Dundee Institute of Technology, \\ Dundee DD1 1HG, UK
}

\begin{abstract}
In the presence of ATP, the motility of demembranated fowl spermatozoa was vigorous at $30^{\circ} \mathrm{C}$, but negligible at $40^{\circ} \mathrm{C}$. Motility could be restored at $40^{\circ} \mathrm{C}$ by the addition of 10-100 ng trypsin $\mathrm{ml}^{-1}$. Chymotrypsin also stimulated the motility, but neither papain nor carboxypeptidase B appreciably affected motility. Conversely, at $30^{\circ} \mathrm{C}$ sperm motility was inhibited by aprotinin or phenylmethylsulfonyl fluoride. These results suggest that endogenous protease, presumably serine protease, activity is instrumental in the regulation of fowl sperm motility. It seems likely that the site of action of this protease is axonemal, but a direct effect of added protease on dynein ATPase activity could not be demonstrated.
\end{abstract}

\section{Introduction}

Flagellar movement of spermatozoa is based on the active sliding of microtubules as a result of ATP hydrolysis by dynein ATPase (for review, see Tash and Means, 1983; Lindemann and Kanous, 1989). Although this basic axonemal mechanism is fairly well understood, the factors and mechanisms of its regulation have still to be clarified. There appear to be several regulatory mechanisms that individually or synergistically control sperm motility: $\mathrm{Ca}^{2+}$ and $\mathrm{Ca}^{2+}$-associated compounds, cAMP and intracellular $\mathrm{pH}$ (Majumder et al., 1990). In addition, current evidence suggests that a protease activity with a Lysand Arg-ester bond specificity is required for sperm motility. It is assumed that this regulatory system is probably located near the dynein arms, but does not directly involve the forcegenerating dynein ATPase (de Lamirande et al., 1990).

Unlike mammalian spermatozoa, fowl spermatozoa show definitive temperature-dependent changes in their motility: in most synthetic diluents, they become immotile at the avian body temperature of $40-41^{\circ} \mathrm{C}$, and motility is restored by decreasing the temperature (Munro, 1938; Nevo and Schindler, 1968; Ashizawa and Nishiyama, 1978; Takeda, 1982; Ashizawa and Okauchi, 1984; Ashizawa and Wishart, 1987; Wishart and Ashizawa, 1987; Ashizawa et al., 1989a, b; Thomson and Wishart, 1989, 1991). The axoneme itself appears to be directly involved in this regulatory system, since the motility of demembranated spermatozoa is, as with intact spermatozoa, negligible at $40^{\circ} \mathrm{C}$ and restored at $30^{\circ} \mathrm{C}$ (Ashizawa et al., $1989 a, b)$. Furthermore, cAMP-independent phosphorylation of a $43 \mathrm{kDa}$ axonemal protein is likely to be a regulatory step in the maintenance of fowl sperm motility (Ashizawa $e t$ al., 1992).

Received 10 November 1992
If the activity of endogenous proteases is involved in the above temperature-dependent regulatory system, then fowl spermatozoa might be expected to be made immotile at $30^{\circ} \mathrm{C}$ by the addition of protease inhibitors and, conversely, motile at $40^{\circ} \mathrm{C}$ by the addition of appropriate exogenous proteases. In this study, the effects of some proteases and protease inhibitors on the motility of demembranated fowl spermatozoa were therefore examined at $30^{\circ} \mathrm{C}$ and $40^{\circ} \mathrm{C}$, and information was obtained concerning the locus of action of such proteases.

\section{Materials and Methods}

\section{Animals and preparation of spermatozoa}

Commercial White Leghorn roosters (Babcock strain, Akagi Poultry Breeding Farm, Miyazaki) were used throughout the study. All birds were housed in individual cages and fed ad libitum on a commercial breeder diet. They were exposed to a $14 \mathrm{~h}$ light:10 h dark cycle.

Semen was collected by the method of Bogdonoff and Shaffner (1954). Samples of semen pooled from four to six males were diluted approximately tenfold in $150 \mathrm{mmol} \mathrm{NaCl} l^{-1}$ with $20 \mathrm{mmol}$ TES ( $N$-Tris-[hydroxymethyl]-methyl-2-aminoethanesulfonic acid) $\mathrm{l}^{-1}$ at $\mathrm{pH} 7.4$ and centrifuged at $700 \mathrm{~g}$ for $13 \mathrm{~min}$ at room temperature $\left(20-25^{\circ} \mathrm{C}\right)$. The washed spermatozoa was reconstituted in the same buffer to give a final concentration of approximately $1 \times 10^{9}$ cells ml ${ }^{-1}$. Samples of 3-4 ml were poured into $30 \mathrm{ml}$ Erlenmeyer flasks with a screw cap.

\section{Chemicals}

Trypsin (approximately 10000 BALL $A_{253}$ units $\mathrm{mg}^{-1}$ protein) was obtained from Mochida Pharmaceutical Co. Down loaded from Bioscientifica.com at 04/26/2023 $01: 21: 42 \mathrm{PM}$
via free access 
(Tokyo). Chymotrypsin (40-60 BTEE $\mu \mathrm{mol} \mathrm{mg}^{-1}$ protein), papain (10-20 BAEE $\mu \mathrm{mol} \mathrm{mg}^{-1}$ protein), carboxypeptidase $B$

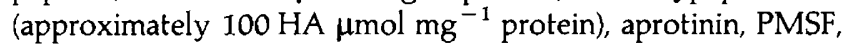
adenosine $5^{\prime}$-triphosphate (ATP), dithiothreitol, potassium glutamate, TES, Triton X-100, phosphodiesterase and desiccated firefly tails were purchased from Sigma Chemical Co. (St Louis, MO). $\left[\gamma_{-}{ }^{32} \mathrm{P}\right] \mathrm{ATP}$ was purchased from Du Pont-New England Nuclear (Boston, MA). Sodium dodecyl sulfate-polyacrylamide gel electrophoresis (SDS-PAGE) molecular weight standards were obtained from Bio-Rad Laboratories (Richmond, CA). Other chemicals were of reagent grade from Nacalai Tesque, Inc. (Kyoto).

\section{Measurement of motility of demembranated spermatozoa}

Intact spermatozoa were preincubated at $30^{\circ} \mathrm{C}$ or $40^{\circ} \mathrm{C}$ for $10 \mathrm{~min}$. After the preincubation, demembranation and reactivation were performed according to the method described by Ashizawa et al. (1989b). The extraction medium used consisted of $0.1 \%$ Triton $X-100,0.2 \mathrm{~mol}$ sucrose $\mathrm{I}^{-1}, 25 \mathrm{mmol}$ potassium glutamate $\mathrm{l}^{-1}, 1 \mathrm{mmol} \mathrm{MgSO} 4 \mathrm{l}^{-1}, 1 \mathrm{mmol}$ dithiothreitol $\mathrm{l}^{-1}$ and $20 \mathrm{mmol}$ Tris- $\mathrm{HCl}$ buffer $\mathrm{l}^{-1}(\mathrm{pH} 7.9)$. The reactivation medium consisted of $0.5 \mathrm{mmol}$ ATP $\mathrm{l}^{-1}, 0.2 \mathrm{~mol}$ sucrose $\mathrm{l}^{-1}$, $25 \mathrm{mmol}$ potassium glutamate $\mathrm{I}^{-1}, 1.5 \mathrm{mmol} \mathrm{MgSO}_{4} \mathrm{I}^{-1}$, $1 \mathrm{mmol}$ dithiothreitol $\mathrm{1}^{-1}$ and $20 \mathrm{mmol}$ Tris- $\mathrm{HCl}$ buffer $1^{-1}(\mathrm{pH} 7.9)$. To examine the effects of exogenous proteases or protease inhibitors, various concentrations of trypsin, chymotrypsin, papain or carboxypeptidase $\mathrm{B}$ at $40^{\circ} \mathrm{C}$, and aprotinin or PMSF at $30^{\circ} \mathrm{C}$ were added to the reactivation medium. Phosphodiesterase, EGTA or $\mathrm{Ca}^{2+}$ were also added to trypsintreated spermatozoa. The suspension of demembranated spermatozoa was viewed in a microscope slide chamber (Sekisui Chemical Co., Ltd, Tokyo, UR-157 type) on a thermostatically controlled warm plate, and the motility of spermatozoa was recorded by videomicroscopy at $30^{\circ} \mathrm{C}$ or $40^{\circ} \mathrm{C}$ (Katz and Overstreet, 1981).

\section{Measurement of crude dynein ATPase activity}

Crude dynein extract from fowl spermatozoa was obtained by the method described by Ashizawa and Hori (1990). ATPase activities were assayed by the reduction of ATP concentrations determined by firefly bioluminescence (Ashizawa and Hori, 1990). Protein concentrations of crude dynein extract were determined according to published methods (Bradford, 1976), with BSA as the standard. The rate of ATPase activity was expressed in terms of nmol ATP hydrolysed $\mathrm{mg}^{-1}$ protein $\min ^{-1}$.

\section{Phosphorylation of endogenous proteins and electrophoresis}

Phosphorylation reaction and electrophoresis on polyacrylamide gels of demembranated sperm proteins were carried out according to the methods described by Ashizawa et al. (1992). Briefly, demembranated spermatozoa with extraction-reactivation medium containing $0.1 \%$ Triton $\mathrm{X}-100,0.2 \mathrm{~mol}$ sucrose $\mathrm{I}^{-1}, 25 \mathrm{mmol}$ potassium glutamate $\mathrm{I}^{-1}, 1 \mathrm{mmol} \mathrm{MgSO}_{4} \mathrm{I}^{-1}$, $1 \mathrm{mmol}$ dithiothreitol $\mathrm{l}^{-1}, 20 \mathrm{mmol}$ Tris- $\mathrm{HCl}$ buffer $\mathrm{l}^{-1}$ (pH 7.9), $0.1 \mathrm{mmol}$ ATP $\mathrm{I}^{-1}$ and approximately 7000 c.p.m. $\left[\gamma_{-}^{32} \mathrm{P}\right] \mathrm{ATP} \mathrm{pmol}^{-1}$ were incubated for $2 \mathrm{~min}$ at $30^{\circ} \mathrm{C}$ or $40^{\circ} \mathrm{C}$. Aprotinin or trypsin, when incorporated, was present at a final concentration of $0.24 \mathrm{TIU}$ (trypsin inhibitor unit) $\mathrm{ml}^{-1}$ or $50 \mathrm{ng} \mathrm{ml}^{-1}$, respectively. The phosphorylation reaction was terminated by the addition of equal volumes of concentrated (twofold) Laemmli (1970) sample buffer and boiling for $5 \mathrm{~min}$. Samples containing protein from approximately $1.3 \times 10^{6}$ spermatozoa were loaded on to $10 \%$ SDS-polyacrylamide slab gels, and electrophoresed. Autoradiography was performed at $-80^{\circ} \mathrm{C}$ for $2-4$ days exposure to $\mathrm{X}$-ray film with an intensifying screen (Lightning plus, Du Pont, Wilmington, DE).

\section{Statistical analysis}

Statistical comparisons were performed using Student's $t$ test.

\section{Results}

\section{Effects of proteases and protease inhibitors on the motility of demembranated fowl spermatozoa}

Reactivation of fowl spermatozoa without the addition of trypsin was negligible at $40^{\circ} \mathrm{C}$. In contrast, the presence of 10$100 \mathrm{ng}$ trypsin $\mathrm{ml}^{-1}$ permitted reactivation of sperm motility at $40^{\circ} \mathrm{C}$, and optimum reactivation occurred at $50 \mathrm{ng}$ trypsin $\mathrm{ml}^{-1}$. At higher concentrations, fewer spermatozoa were reactivated (Fig. 1a). Chymotrypsin also stimulated the motility of demembranated spermatozoa at $40^{\circ} \mathrm{C}$, and maximum motility was obtained at $600 \mathrm{ng}$ chymotrypsin $\mathrm{ml}^{-1}$ (Fig. Ib). However, no stimulation of motility was observed following the addition of papain (Fig. 1a) or carboxypeptidase B (Fig. Ib), within the ranges $0-2 \mu \mathrm{g} \mathrm{ml}^{-1}$ and $0-500 \mu \mathrm{g} \mathrm{ml}^{-1}$, respectively, and disintegration of sperm tails was observed at higher concentrations. The addition of papain and carboxypeptidase B at lower concentrations ( $\mathrm{ng} \mathrm{ml} \mathrm{m}^{-1}$ ) was also ineffective in initiating motility (data not shown).

However, the vigorous motility of demembranated spermatozoa at $30^{\circ} \mathrm{C}$ was inhibited in a dose-dependent manner by the addition of the protease inhibitors, aprotinin or PMSF (Fig. 2). However, the addition of $500 \mathrm{ng}$ trypsin $\mathrm{ml}^{-1}$ released the inhibitory effect of aprotinin within 1 min (Fig. 3).

Neither the addition of phosphodiesterase to remove endogenous CAMP nor the addition of $\mathrm{Ca}^{2+}$ or EGTA to trypsin-treated spermatozoa had any significant effect on sperm motility at $40^{\circ} \mathrm{C}$ (Table 1 ).

\section{Effects of proteases on dynein ATPase activity and the phosphorylation state of proteins of demembranated fowl spermatozoa}

The flagellar ATPase activity of crude dynein extract without the addition of proteases was approximately $22 \mathrm{nmol}$ ATP hydrolysed $\mathrm{mg}^{-1}$ protein $\mathrm{min}^{-1}$. This activity was not stimulated by the addition of proteases, including trypsin and chymotrypsin (Table 2).

A marked difference in the phosphorylation status of a $43 \mathrm{kDa}$ protein was obtained in demembranated spermatozoa at $30^{\circ} \mathrm{C}$ and at $40^{\circ} \mathrm{C}$. This protein was slightly phosphorylated 

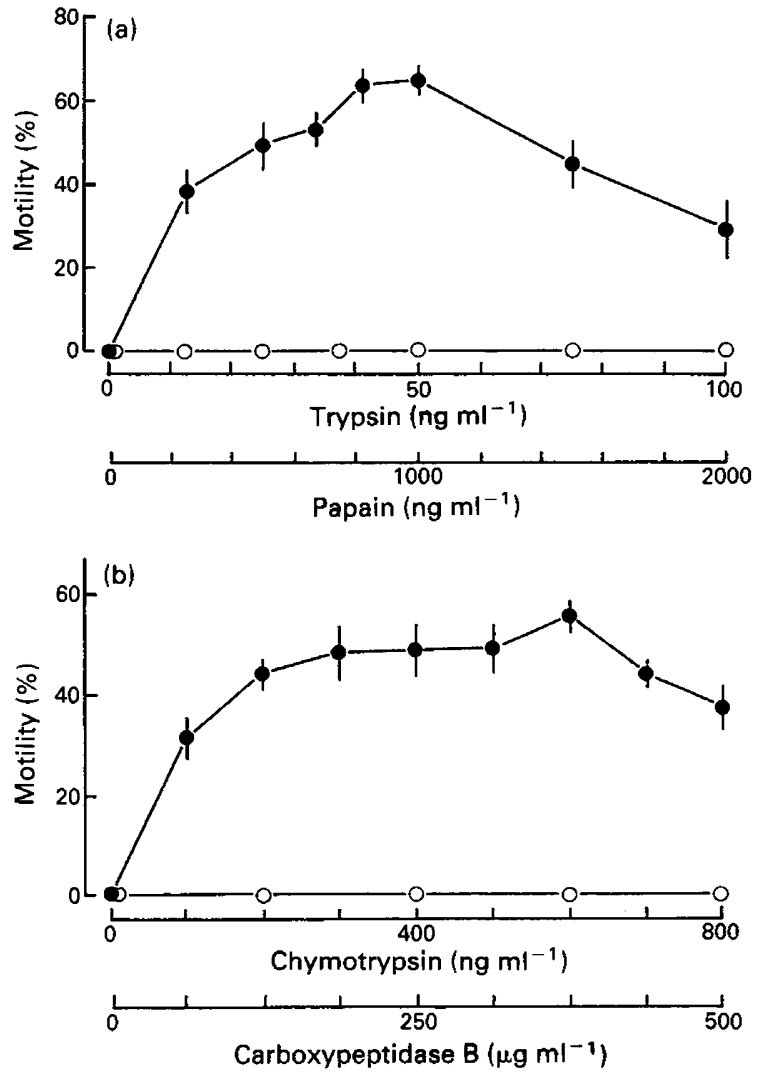

Fig. 1. The motility of demembranated fowl spermatozoa in the reactivation medium at $40^{\circ} \mathrm{C}$ after addition of various concentrations of (a) (O) trypsin or (O) papain and (b) chymotrypsin (O) or carboxypeptidase $B(O)$. Results are the mean $( \pm \mathrm{SEM})$ from five samples of spermatozoa.

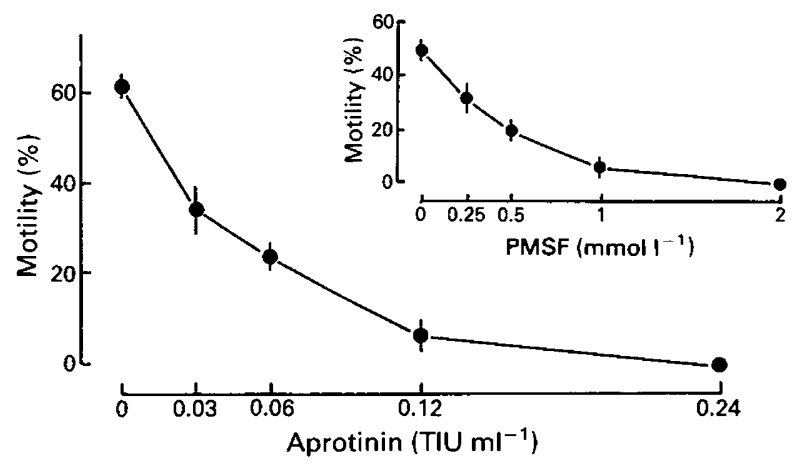

Fig. 2. The motility of demembranated fowl spermatozoa in the reactivation medium at $30^{\circ} \mathrm{C}$ after addition of various concentrations of aprotinin or phenylmethylsulfonyl fluoride (PMSF). Results are the mean $( \pm S E M)$ from five samples of spermatozoa. TIU: trypsin inhibitor units.

at $40^{\circ} \mathrm{C}$, but strongly phosphorylated at $30^{\circ} \mathrm{C}$, confirming the previous observation of Ashizawa et al. (1992). However, neither aprotinin at $30^{\circ} \mathrm{C}$ nor trypsin at $40^{\circ} \mathrm{C}$ affected the phosphorylated state of this or other phosphorylated proteins (Fig. 4).

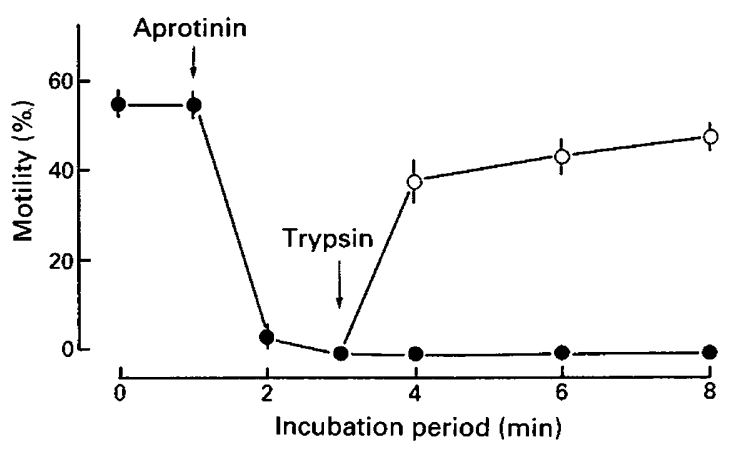

Fig. 3. The motility of demembranated fowl spermatozoa in the reactivation medium at $30^{\circ} \mathrm{C}$ following addition of (O) 0.24 trypsin inhibitor units aprotinin $\mathrm{ml}^{-1}$ or (O) $500 \mathrm{ng}$ trypsin $\mathrm{ml}^{-1}$. Results are the mean ( $\pm \mathrm{SEM}$ ) from five samples of spermatozoa.

Table 1. The effects of phosphodiesterase, EGTA and $\mathrm{Ca}^{2+}$ on the motility of trypsin-treated demembranated fowl spermatozoa at $40^{\circ} \mathrm{C}$

Treatments

Motility

(\%)

None (control)

Trypsin (50 $\mathrm{ng} \mathrm{ml}^{-1}$ )

$4.8 \pm 1.9^{\mathrm{a}}$

Trypsin $\left(50 \mathrm{ng} \mathrm{ml}^{-1}\right)+$ phosphodiesterase $\left(2 \mathrm{U} \mathrm{ml}^{-1}\right) \quad 70.5+5.3^{\mathrm{b}}$

EGTA $\left(2 \mathrm{mmol}^{-1}\right)$

$4.1 \pm 1.8^{\mathrm{a}}$

$\mathrm{Ca}^{2+}\left(0.1 \mu \mathrm{mol} \mathrm{l}^{-1}\right)$

$2.7 \pm 1.3^{\mathrm{a}}$

Trypsin $\left(50 \mathrm{ng} \mathrm{m}^{-1}\right)+$ EGTA $\left(2 \mathrm{mmoll}^{-1}\right)$

Trypsin $\left(50 \mathrm{ng} \mathrm{ml}^{-1}\right)+\mathrm{Ca}^{2+}\left(0.1 \mu \mathrm{mol} \mathrm{l}^{-1}\right)$

$72.1 \pm 3.5^{\mathrm{b}}$

$70.4 \pm 2.6^{b}$

Each value represents the mean ( $\pm \mathrm{SEM}$ ) of five samples of spermatozoa. Values with different superscripts differ significantly $(P<0.01)$ from each other.

Table 2. The effects of proteases on the ATPase activity of crude dynein extract of fowl spermatozoa at $40^{\circ} \mathrm{C}$

\begin{tabular}{lc}
\hline Protease & $\begin{array}{c}\text { ATPase activity } \\
(\mathrm{nmol} \text { ATP hydrolysed } \\
\mathrm{mg}^{-1} \text { protein min }\end{array}$ \\
\hline None (control) & $21.8 \pm 0.3^{\mathrm{a}}$ \\
Trypsin $\left(50 \mathrm{ng} \mathrm{m}^{-1}\right)$ & $20.5 \pm 0.7^{\mathrm{a}}$ \\
Chymotrypsin $\left(600 \mathrm{ng} \mathrm{ml}^{-1}\right)$ & $20.9 \pm 0.9^{\mathrm{a}}$ \\
Papain $\left(600 \mathrm{ng} \mathrm{ml}^{-1}\right)$ & $20.9 \pm 0.7^{\mathrm{a}}$ \\
Carboxypeptidase B $\left(40 \mu \mathrm{g} \mathrm{ml}^{-1}\right)$ & $21.0 \pm 0.3^{\mathrm{a}}$ \\
\hline
\end{tabular}

Each value represents the mean ( \pm SEM) of five samples of spermatozoa. Values with different superscripts differ significantly $(P<0.01$ ) from each other.

\section{Discussion}

Protease activities were mainly thought to be involved in the catabolism of proteins, but recent evidence suggests that they 


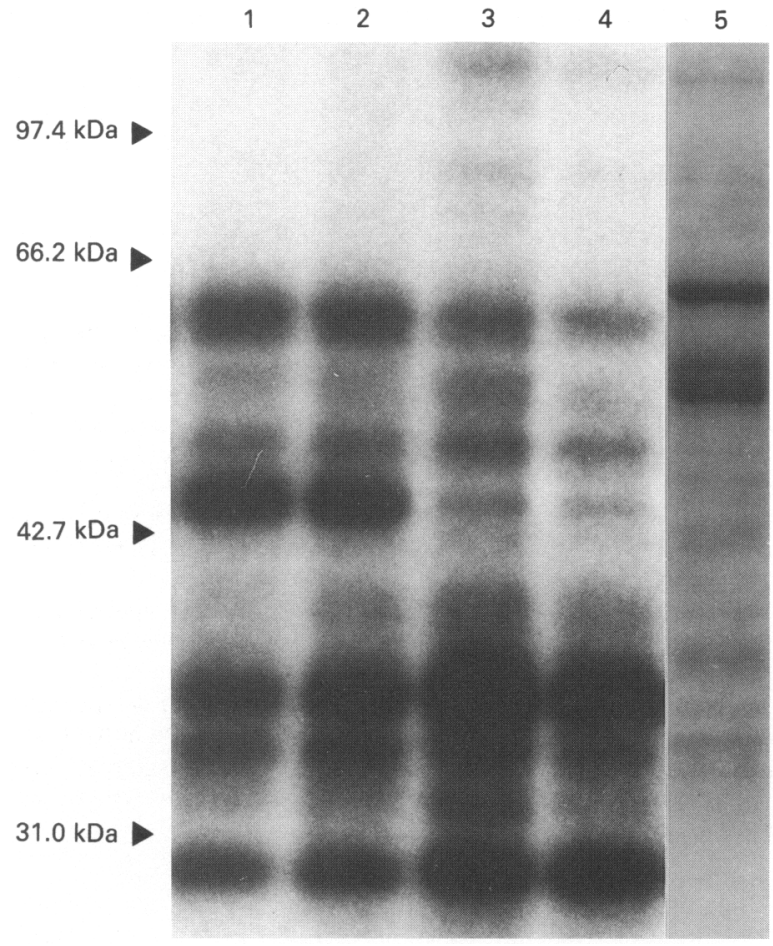

Fig. 4. 10\% SDS-PAGE profile of demembranated fowl sperm proteins stained with Coomassie blue (lane 5) and corresponding autoradiography of phosphorylated proteins (lanes 1-4). Triton X-100 extracted and reactivated samples were incubated at $30^{\circ} \mathrm{C}$ or $40^{\circ} \mathrm{C}$ for $2 \mathrm{~min}$. Lane $1: 30^{\circ} \mathrm{C}$ in the absence of aprotinin; lane $2: 30^{\circ} \mathrm{C}$ in the presence of 0.24 trypsin inhibitor units aprotinin $\mathrm{ml}^{-1}$; lane $3: 40^{\circ} \mathrm{C}$ in the absence of trypsin; lane $4: 40^{\circ} \mathrm{C}$ in the presence of $50 \mathrm{ng}$ trypsin $\mathrm{ml}^{-1}$.

also have a short-term regulatory function, for example in the control of sperm motility (Gagnon and de Lamirande, 1987). The present study showed that temperature-dependent immobilization of demembranated fowl spermatozoa at $40^{\circ} \mathrm{C}$ was reversed by the addition of trypsin or chymotrypsin. Furthermore, sperm motility at $30^{\circ} \mathrm{C}$ was inhibited by aprotinin or PMSF, but could be restored by the subsequent addition of trypsin. It is therefore proposed that an endogenous, presumably serine, protease is present in the fowl sperm axoneme, and plays an important role in regulating sperm movement. The immobilization of fowl spermatozoa at $40^{\circ} \mathrm{C}$ might be due in part to the reduction of activity of this protease, although the effects of temperature on the activity of proteases of fowl spermatozoa were not measured in this experiment.

Although this is the first report of the presence of such protease activity in avian spermatozoa, similar sperm proteases appear to be preserved throughout evolution from sea urchins to humans (de Lamirande et al., 1990), as protease inhibitors, including aprotinin, inhibited the motility of demembranated spermatozoa in sea urchins, fish and mammals (de Lamirande et al., 1983; de Lamirande and Gagnon, 1986; Cosson and Gagnon, 1988; Inaba and Morisawa, 1991).

The target and precise mechanisms of action of proteases in the regulation of sperm motility remain to be elucidated. The inhibition of motility initiation by high concentrations of ATP was abolished by the inclusion of trypsin in demembranated hamster spermatozoa, and it is assumed that trypsin may involve the action of cAMP (Yeung, 1986), since a trypsinlike protease derived from bovine spermatozoa can stimulate adenylyl cyclase (Johnson et al., 1985). In the present study, however, no decrease in motility was observed by the addition of phosphodiesterase to remove endogenous cAMP from trypsin-treated spermatozoa. Moreover, trypsin-stimulated sperm motility was not affected by the removal or addition of $\mathrm{Ca}^{2+}$. From these results, it may be proposed that the proteases act directly on the axoneme in a cAMP- and $\mathrm{Ca}^{2+}$-independent manner. However, the results reported here also showed that ATPase activity of a dynein extract of fowl spermatozoa was not stimulated by the addition of proteases tested, suggesting that these proteases might not act directly on dynein ATPase. Similarly, trypsin did not stimulate the steady-state activity of the axonemal dynein ATPase of sea urchin spermatozoa (Kamimura et al., 1985) and aprotinin, at 50-fold the concentration needed to block sperm motility, caused only a $30 \%$ inhibition of dynein ATPase isolated from bull spermatozoa (Gagnon and de Lamirande, 1987).

Recently, we suggested that cAMP-independent phosphorylation of a $43 \mathrm{kDa}$ axonemal protein is likely to be a regulatory step in the maintenance of fowl sperm motility (Ashizawa et al., 1992). However, the phosphorylation state of this protein did not change in the presence of proteases or their inhibitors, which supports the hypothesis that the site of action of endogenous protease may lie between the $43 \mathrm{kDa}$ protein and the dynein-tubulin sliding system. This hypothesis agrees with the suggestion that other sperm proteases may act near the site where dynein arms interact with microtubules, without affecting the dynein ATPase (de Lamirande et al., 1990).

This study was supported by a grant from the Ministry of Education, Science and Culture, Japan. G. J. Wishart was supported by the Royal Society of Edinburgh.

\section{References}

Ashizawa K and Hori M (1990) Activation of dynein adenosine triphosphatase and flagellar motility of demembranated spermatozoa by monovalent salts at $40^{\circ} \mathrm{C}$ in the domestic fowl, Gallus domesticus Comparative Biochemistry and Physiology 97A 325-328

Ashizawa K and Nishiyama H (1978) Effects of temperature on the vigour of motility, oxygen consumption and duration of motility of fowl spermatozoa under aerobic conditions Japanese Poultry Science 15 264-266

Ashizawa K and Okauchi K (1984) Stimulation of sperm motility and oxygen consumption of fowl spermatozoa by a low molecular weight fraction of seminal plasma Journal of Reproduction and Fertility 71 593-598

Ashizawa K. and Wishart GJ (1987) Resolution of the sperm motilitystimulating principle of fowl seminal plasma into $\mathrm{Ca}^{2+}$ and an unidentified low molecular weight factor Journal of Reproduction and Fertility $\mathbf{8 1}$ 495-499

Ashizawa K, Maeda S and Okauchi K (1989a) The mechanisms of reversible immobilization of fowl spermatozoa at body temperature Joumal of Reproduction and Fertility 86 271-276

Ashizawa K, Suzuki Y and Okauchi K (1989b) Flagellar movement in demembranated preparations of ejaculated fowl spermatozoa Journal of Reproduction and Fertility 86 263-270

Ashizawa K, Katayama S and Tsuzuki Y (1992) Regulation of flagellar motility by temperature-dependent phosphorylation of a $43 \mathrm{kDa}$ axonemal protein in fowl spermatozoa Biochemical and Biophysical Research Communications 185 $740-745$

Bogdonoff PD Jr and Shaffner CS (1954) The effect of $\mathrm{pH}$ on in vitro survival metabolic activity, and fertilizing capacity of chicken semen Poultry Science 33 $665-669$

Downloaded from Bioscientifica.com at 04/26/2023 01:21:42PM 
Bradford MM (1976) A rapid and sensitive method for the quantitation of microgram quantities of protein utilizing the principle of protein-dye binding Analytical Biochemistry 72 248-254

Cosson MP and Gagnon C (1988) Protease inhibitor and substrates block motility and microtubule sliding of sea urchin and carp spermatozoa Cell Motility and the Cytoskeleton 10 518-527

de Lamirande E and Gagnon C (1986) Effects of protease inhibitors and sub. strates on motility of mammalian spermatozoa Journal of Cell Biology 102 1378-1383

de Lamirande E, Bardin CW and Gagnon C (1983) Aprotinin and a seminal plasma factor inhibit the motility of demembranated reactivated rabbit spermatozoa Biology of Reproduction 28 788-796

de Lamirande E, Cosson MP and Gagnon C (1990) Protease involvement in sperm motility. In Controls of Sperm Motility: Biological and Clinical Aspects pp 241-250 Ed. C Gagnon. CRC Press, Boca Raton

Gagnon $C$ and de Lamirande $E$ (1987) Protease involvement in sperm motility. In New Horizons in Sperm Cell Research pp 205-214 Ed. H Mohri. Japan Scientific Societies Press, Tokyo

Inaba $\mathbf{K}$ and Morisawa $\mathbf{M}$ (1991) A chymotrypsin-like protease involved in motility of sperm in salmonid fish Biomedical Research 12 4.35-437

Johnson RA, Jakobs KH and Schultz G (1985) Extraction of the adenylate cyclase-activating factor of bovine sperm and its identification as a trypsinlike protease Joumal of Biological Chemistry 260 114-121

Kamimura S, Yano M and Shimizu H (1985) ATP hydrolysis coupled to microtubule sliding in sea-urchin sperm flagella Joumal of Biochemistry 97 1509-1515

Katz DF and Overstreet JW (1981) Sperm motility assessment by videomicrography Fertility and Sterility 35 188-193

Laemmli UK (1970) Cleavage of structural proteins during the assembly of the head of bacteriophage T4 Nature 227 680-685
Lindemann CB and Kanous KS (1989) Regulation of mammalian sperm motility Archives of Andrology 23 1-22

Majumder GC, Dey CS, Haldar S and Barua M (1990) Biochemical parameters of initiation and regulation of sperm motility Archives of Andrology 24 287-303

Munro SS (1938) Fowl sperm immobilization by a temperature-media interaction and its biological significance Quarterly Journal of Experimental Physiology $27281-287$

Nevo AC and Schindler H (1968) Reversible inactivation of cock spermatozoa by temperature. Proceedings of the Sixth international Congress of Animal Reproduction and Artificial Insemination, Paris, II, 1637-1640

Takeda A (1982) Studies on reversible inactivation of cock spermatozoa by temperature. I. Effects of several factors on reversible inactivation Japanese Poultry Science 19 26-36

Tash JS and Means AR (1983) Cyclic adenosine 3',5' monophosphate, calcium and protein phosphorylation in flagellar motility Biology of Reproduction $\mathbf{2 8}$ 75-104

Thomson MF and Wishart GJ (1989) Elucidation of the mechanism responsible for the temperature-dependent reversible inactivation of the motility of fowl spermatozoa British Poultry Science $30687-692$

Thomson MF and Wishart GJ (1991) Temperature-mediated regulation of calcium flux and motility in fowl spermatozoa Joumal of Reproduction and Fertility 93 385-391

Wishart GJ and Ashizawa K (1987) Regulation of motility of fowl spermatozoa by calcium and CAMP Journal of Reproduction and Fertility 80 607-611

Yeung CH (1986) Temporary inhibition of the initiation of motility of demembranated hamster sperm by high concentrations of ATP International journal of Andrology 9 359-370 